\title{
DYNAMICS IN MEDICAL TREATMENT OF ISCHEMIC HEART DISEASE IN CLINICAL PRACTICE
}

\author{
S.A. Shalnova, A.D. Deev, A.S. Boytsov* \\ State Research Center for Preventive Medicine. Petroverigsky per. 10, Moscow, 101990 Russia
}

At the present time ischemic heart disease (IHD) continues to be the leading cause of cardiovascular mortality. Improvement of treatment methods is an important aspect in reduction of IHD fatal complications.

Aim. To carry out a meta-analysis of several clinical and epidemiological studies with research on the use of drugs with established prognostic effect in patients with IHD.

Material and methods. Analysis of dynamics in drug prescription in IHD was conducted based on Russian clinical and epidemiological trials, performed from 2004 to 2009 years.

Results. The total amount of patients was 17345. Majority of them suffered from arterial hypertension (81.6\%), one third had a history of myocardial infarction, more than a half revealed heart failure (59.8\%). At that history of diabetes mellitus was only registered in $10.5 \%$ of the patients varying from $8 \%$ to $17.6 \%$. Lipid metabolism disorders were present in more than a half of the patients. On the average one in four patients was obese.

At drug therapy analysis it was found out that $6.4 \%$ of the IHD patients received no medications. Statins intake increased from $5.3 \%$ to $85.7 \%$ in men and from $9.6 \%$ to $69.3 \%$ in women in last 5 years. Incidence of the renin-angiotensin-aldosterone system blockers intake increased by $13 \%$ in the both genders. Men with IHD received antiplatelet agents more often than women. So, only $45.9 \%$ of women received these drugs in 2004 and $57.9 \%$ - in 2009, while men increased antiplatelet agents use from $58.5 \%$ in 2004 to $63.5 \%$ in 2009 . Men received beta-blockers by $14 \%$ more often in 2009 (74.6\%) than in 2004 and women - by $30 \%(82.4 \%)$.

Conclusion. The incidence of the prescription of the drugs with established prognostic value has increased recently. At that rate of IHD mortality in cardiovascular mortality structure continues to be high probably due to inadequate treatment. First, the number of coronary surgical interventions in our patients is significantly lower than in the other countries. Second, despite considerable increase in the drug use, doses and adherence to treatment remain insufficient. Representative trials with participation of different-level healthcare institutions are reasonable.

Key words: coronary heart disease; medical treatment; clinical practice.

Ration Pharmacother Cardiol 2013;9(6):611-618

Динамика лекарственной терапии при ишемической болезни сердца в клинической практике
С.А. Шальнова, А.Д. Деев, А.С. Бойцов*
Государственный научно-исследовательский центр профилактической медицины. 101990 Москва, Петроверигский пер., 10

Ишемическая болезнь сердца (ИБС) в настоящее время остается ведущей причиной сердечно-сосудистой смертности. Совершенствование методов лечения является важным компонентом уменьшения фатальных осложнений у больных ИБС.

Цель. Проанализировать совместно несколько клинико-эпидемиологических исследований по изучению использования классов лекарственных препаратов, обладающих доказанным прогностическим эффектом у больных ИБС.

Материал и методы. Анализ динамики назначений лекарственных препаратов при ИБС был проведен на основе данных российский клинико-эпидемиологических исследований, проведенных с 2004 по 2009 гг.

Результаты. Общее число больных составило 17345, большинство из которых страдали артериальной гипертонией (81,6\%), треть имели в анамнезе инфаркт миокарда, более половины имели сердечную недостаточность (59,8\%). В то же время сахарный диабет в анамнезе зарегистрирован только у 10,5\%, варьируя от 8\% до 17,6\%. Более чем у половины определялось нарушение липидного обмена. Каждый четвертый в среднем имел ожирение.

При анализе лекарственной терапии оказалось, что 6,4 \% больных ИБС вообще не принимали лекарственных препаратов. Прием статинов за пять последних лет увеличился с 5,3\% до 85,7\% у мужчин и с 9,6\% до 69,3\% - у женщин. Частота приема блокаторов ренин-ангиотензин-альдостероновой системы увеличилась на $13 \%$ у лиц обоего пола. Мужчины, страдающие ИБС, чаще принимают антитромбоцитарные препараты (АТП), чем женщины. Так, в 2004 г. только 45,9\% женщин принимали этот класс препаратов; в 2009 г. 57,9\%, тогда как прием антитромбоцитарных препаратов у мужчин увеличился с 58,5\% в 2004 г. до 63,5\% в 2009 г. Бета-адреноблокаторы в 2009 г. мужчины принимали на $14 \%$ чаще (74,6\%), чем в 2004 г., а женщины - на 30\% (82,4\%).

Заключение. Частота назначения препаратов, обладающих прогностически доказанным действием, увеличилась за последние годы. Вместе с тем, доля смертности от ИБС в структуре смертности от сердечно-сосудистых заболеваний остается высокой, что может быть связано с неадекватным лечением. Во-первых, число хирургических вмешательств на коронарных артериях у наших больных значительно ниже, чем в других странах. Во-вторых, несмотря на существенное увеличение частоты применения лекарственных препаратов, дозы и постоянство приема остаются недостаточными. Целесообразно проведение представительных исследований с привлечением лечебно-профилактических учреждений разного уровня.

Ключевые слова: ишемическая болезнь сердца, лекарственная терапия, клиническая практика.

Рациональная фармакотерапия в кардиологии 2013;9(6):611-618

*Corresponding author (Автор, ответственный за переписку): prof-boytsov@mail.ru

Decrease in cardiovascular mortality rate in majority of developed countries is one of the most important accomplishments of cardiology in the second half of the preceding century. Thus, according to the Fox C.S. et al. data (2004) ischemic heart disease (IHD) mortality, including sudden death, has reduced by 59\% in the USA from 1950-1969 to

\footnotetext{
Authors' information:

Svetlana A. Shalnova - PhD, MD, Professor, Head of Department of Non-infectious Diseases Epidemiology, State Research Center for Preventive Medicine (SRCPM) Alexander D. Deev - PhD, Head of Laboratory of Biostatistics, SRCPM

Sergey A. Boytsov - PhD, MD, Professor, Director of the SRCPM, Head of Department of Clinical Cardiology and Molecular Genetics of the SRCPM
}

Одним из важнейших достижений кардиологии второй половины предыдущего столетия можно считать снижение смертности от сердечно-сосудистых заболеваний (ССЗ) в большинстве развитых стран. Так, по данным Fox C.S. и соавт. (2004) смертность от ишемической болезни сердца (ИБС), включая внезапную смерть, с 1950-1969 по 19901999 гг. в США снизилась на 59\% [1,2]. Весьма впечатляют

\footnotetext{
Сведения об авторах:

Шальнова Светлана Анатольевна - Д.М.Н., профессор, руководитель отдела эпидемиологии неинфекционных заболеваний ГНИЦ ПМ

Деев Александр Дмитриевич - к.ф. м.н., руководитель лаборатории медицинской биостатистики того же центра Бойцов Сергей Анатольевич - д.м.Н., профессор, директор ГНИЦ ПМ, руководитель отдела клинической кардиологии и молекулярной генетики того же центра
} 
1990-1999 [1,2]. Finland with one of the highest IHD mortality rates in Europe in 1960-th years has achieved decline in this index by $75 \%$ due to implementation of the North Karelian preventive project [3]. Russia has also demonstrated some success in this field, even though rather modest: IHD mortality rates decreased by $11.1 \%$ from 2003 to 2012 years. At that IHD continues to be the leading cause of cardiovascular death in our country. A total of 393.1 deaths per 100000 population was registered in Russia in 2012, while the similar index in the USA was 116.1 per 100000 [4]. Besides, within general decrease of cardiovascular mortality, rates for cerebrovascular disease mortality decrease more significantly than those for IHD, what results in growth of IHD proportion in the cardiovascular mortality structure.

At the same time cardiovascular morbidity tends to increase. Thus, Heidenreich P. et al. (2011) showed that IHD prevalence in the USA would be incremented by $16.6 \%$ from 2010 to 2030 and direct costs for its treatment - by $196 \%$. Authors explain expected increase in cardiovascular diseases morbidity by growth of obesity and diabetes mellitus prevalence and also by rise in elderly people population, who, on one hand, have multiple cardiovascular pathology, but on the other hand, benefit from contemporary diagnostic and treatment methods that keep them alive [5].

According to official statistic data our country also demonstrates gradual increase in IHD patients' amount. For instance, the total amount of registered IHD patients in 2000 year was 5437000 including 472000 of newly diagnosed cases. In 2010 year these indices were as much as 7374000 and 707000 , respectively. It is therefore obvious that along with increase in the total amount of IHD patients a number of newly diagnosed IHD persons also grows [6].

Attempts to explain changes in mortality rates have been undertaken for a long time.

Currently a method of estimation of impact of different treatment and preventive strategies on mortality rates has been developed and successfully used [7]. At that, decreased levels of risk factors in population may be explained by benefits of preventive programs. On the other side, improvement, of treatment methods plays an important role in the reduction of IHD fatal complications [3, 8-11].

Russian and international Guidelines emphasize reduction of cardiovascular risk as the first goal of the treatment. For this purpose medications that improve prognosis are recommended for use. In particular, patients with angina pectoris are recommended, if not contraindicated, antiplatelet agents: успехи Финляндии, которая в 1960-х годах имела один из самых высоких показателей смертности от ИБС в Европе. Распространение опыта Северо-Карельского профилактического проекта на все население страны привело к снижению смертности от ИБС на 75\% [3]. Определенные успехи, хотя и очень скромные, отмечаются и в России, где с 2003 г. до 2012 г. смертность от ИБС снизилась на 11,1\%. Вместе с тем, ИБС в нашей стране остается ведущей причиной сердечнососудистой смерти. В 2012 г. в России было зарегистрировано 393,1 смертей на 100000 населения, тогда как в США, например, этот показатель составил 116,1 на 100000 населения [4]. Кроме того, при общем снижении смертности от ССЗ мы имеем более существенное снижение смертности от цереброваскулярной болезни, чем от ИБС, что приводит к увеличению доли смертности от ИБС в структуре смертности от ССЗ.

Наряду с этим положительным явлением сердечно-сосудистая заболеваемость имеет тенденцию к увеличению В частности, Heidenreich Р. и соавт. (2011) показали, что К 2030 г. по сравнению с 2010 г, распространенность ИБС в США увеличится на 16,6\%, а прямые затраты на ее лечение - на 196\%. Авторы объясняют ожидаемое увеличение распространенности ССЗ наблюдаемым ростом ожирения и диабета, а также увеличением доли пожилого населения, отягощенного множеством сердечно-сосудистых патологий, но сохраняющих жизни за счет успехов современных методов диагностики и лечения [5].

Анализ заболеваемости по данным официальной статистики в нашей стране также демонстрирует постепенное увеличение абсолютного числа больных ИБС. Например, в 2000 г. общее число зарегистрированных больных ИБС составило 5437000, в том числе с впервые установленным диагнозом - 472000. В 2010 г. уже 7374000 и 707000, соответственно, имели диагноз ИБС. Таким образом, очевидно, что наряду с увеличением общего числа больных ИБС регистрируется увеличение числа больных с впервые установленным диагнозом [6].

Попытки объяснить те или иные изменения показателей смертности предпринимаются уже давно.

В настоящее время разработана и активно используется методика оценки вклада различных лечебных и профилактических стратегий в наблюдаемые изменения смертности [7]. При этом снижение популяционных уровней факторов риска связывают с успехами профилактических программ. С другой стороны, совершенствование методов лечения является важным компонентом уменьшения фатальных осложнений у больных ИБС [3, 8-11]

В российских и международных Рекомендациях подчеркивается, что первой целью терапии является снижение риска сердечно-сосудистых осложнений, для чего рекомендуется использовать лекарственные препараты, улучшающие прогноз. В частности, больным стенокардией при отсутствии противопоказаний рекомендуются антитромбоцитарные препараты (АТП): ацетил-салициловая кисло- 
acetylsalicylic acid (ASA) and clopidogrel (level of evidence $1 \mathrm{~A}$ ). All the IHD patients are recommended lipid-lowering drugs, in particular, inhibitors of HMG-CoA reductase - statins (1A). Angiotensinconverting enzyme (ACE) inhibitors are indicated in chronic IHD patients with angina or a history of myocardial infarction ( $1 \mathrm{~A}$ ). If not well tolerated these drugs are changed to angiotensin II receptor blockers (ARB). Beta-blockers are recommended in patients with a history of myocardial infarction or with chronic heart failure (CHF; 1A) [12].

This work demonstrates results of the meta-analysis of several clinical and epidemiological studies with research on the use of different drugs with established prognostic value in patients with IHD.

\section{Material and methods}

Analysis of dynamics of drug prescription in IHD patients was carried out based on the following Russian clinical and epidemiological studies data: KOORDINATA [13], OSKAR [14], PREMIERA [15] and PERSPECTIVA [16]. The Table 1 shows a number of the IHD patients enrolled into each of these studies.

The total amount of the IHD patients included in the analysis was 17345: 10959 patients were examined in 2004 year, 3634 - in 2005 and 2752 patients - in 2009.

Statistical analysis was performed with the Statistical package SAS, version 6.12.

\section{Results and discussion}

Characteristics of the patients are presented in the Table 2.

Mean age of all the patients enrolled into the analysis was $63.3 \pm 0.07$ ( $59-66$ years). To compare our results with data from foreign studies standardization of the data to the European standard was carried out. A half of the patients were men. Majority of the IHD patients suffered from arterial hypertension (81.6\%), a third had a history of myocardial infarction, $4-8.6 \%$ of the patients were underwent stroke. A rate of $\mathrm{CHF}$ was rather significant $-59.8 \%$. At that diabetes mel- та и клопидогрел (уровень доказательности 1А). Всем больным ИБС рекомендованы гиполипидемические средства, в частности, ингибиторы ГМГ-КоА редуктазы - статины (1А). Признаки стенокардии напряжения или перенесенный инфаркт миокарда (ИМ) являются показанием к назначению ингибиторов ангиотензин-превращающего фактора (ИАПФ) при хронической ИБС (1А). При плохой переносимости этих препаратов их заменяют на антагонисты рецепторов ангиотензина II (APA). Бета-адреноблокаторы (БАБ) рекомендуются больным после ИМ или при хронической сердечной недостаточности (ХCH; 1А) [12].

В данной работе представлены результаты совместного анализа нескольких клинико-эпидемиологических исследований по изучению использования классов лекарственных препаратов, обладающих доказанным прогностическим эффектом у больных ИБС.

\section{Материал и методы}

Анализ динамики назначений лекарственных препаратов при ИБС был проведен на основе данных российских клинико-эпидемиологических исследований - КООРДИНАТА [13], ОСКАР [14], ПРЕМЬЕРА [15] и ПЕРСПЕКТИВА [16]. В табл. 1 представлено число больных ИБС, ВКлюченных в каждое из исследований.

Общее число пациентов с ИБС, включенное в анализ, составило 17345, в том числе в 2004 г. было обследовано 10959 больных, в 2005 г. - 3634 больных, в 2009 г. - 2752 больных.

Статистический анализ проводился с помощью статистического пакета SAS, версия 6.12.

\section{Результаты и обсуждение}

Характеристика больных представлена в табл. 2.

Средний возраст всех включенных в анализ составил

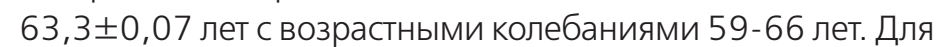
сравнения с данными зарубежных исследований наши результаты приведены по европейскому стандарту. Половина больных были мужчины. Большинство больных ИБС страдали артериальной гипертонией $(81,6 \%)$, треть имели в анамнезе ИМ, от 4\% до 8,6\% больных перенести мозговой инсульт. Обращает на себя внимание весьма существенная доля ХСН (59,8\%). В то же время сахарный диа-

Table 1. Number of IHD patients enrolled into the analysis based on the year of inclusion and gender

Таблица 1. Число больных ИБС, включенное в анализ, в зависимости от года включения в исследование и пола

\begin{tabular}{|c|c|c|c|c|c|c|c|}
\hline \multirow{3}{*}{$\begin{array}{l}\text { Parameter } \\
\text { Параметр } \\
\text { Year of the trial / Год исследования }\end{array}$} & \multicolumn{7}{|c|}{ Trial / Исследование } \\
\hline & \multicolumn{2}{|c|}{$\begin{array}{l}\text { KOORDINATA } \\
\text { КООРДИНАТА }\end{array}$} & \multicolumn{2}{|c|}{$\begin{array}{l}\text { OSKAR } \\
\text { OCKAP }\end{array}$} & \multicolumn{2}{|c|}{$\begin{array}{l}\text { PREMIERA } \\
\text { ПPEMЬEPA }\end{array}$} & \multirow{2}{*}{$\begin{array}{c}\text { PERSPECTIVA } \\
\text { ПЕРСПЕКТИВА } \\
2009\end{array}$} \\
\hline & 2004 & 2005 & 2004 & 2005 & 2004 & 2005 & \\
\hline Men / Мужчины, n & 1224 & 144 & 1437 & 1637 & 2595 & 82 & 1535 \\
\hline Women / Женщины, n & 1722 & 196 & 954 & 1484 & 3027 & 87 & 1217 \\
\hline \multirow[t]{2}{*}{ Total / Всего, n } & 2946 & 320 & 2391 & 3121 & 5622 & 163 & 2752 \\
\hline & \multicolumn{2}{|c|}{3296} & \multicolumn{2}{|c|}{5512} & \multicolumn{2}{|c|}{5785} & 2752 \\
\hline
\end{tabular}


Table 2. Characteristics of the patients enrolled into the analyzed trials

Таблица 2. Характеристика больных, включенных в анализ, соответственно исследованию

\begin{tabular}{|c|c|c|c|c|c|}
\hline Parameter / Параметр & $\begin{array}{l}\text { KOORDINATA } \\
\text { КООРДИНАTA }\end{array}$ & $\begin{array}{l}\text { OSKAR } \\
\text { OCKAP }\end{array}$ & $\begin{array}{l}\text { PREMIERA } \\
\text { ПPEMbEPA }\end{array}$ & $\begin{array}{l}\text { PERSPECTIVA } \\
\text { ПЕРСПЕКTИВA }\end{array}$ & $\begin{array}{l}\text { All patients } \\
\text { Bce пациенты }\end{array}$ \\
\hline Mean age, years / Средний возраст, лет & $65.9 \pm 0.14$ & $59.0 \pm 0.12$ & $61.3 \pm 0.14$ & $59.9 \pm 0.18$ & $63.3 \pm 0.07$ \\
\hline Men / Мужчины, \% & 46.3 & 55.8 & 46.3 & 55.8 & 49.9 \\
\hline History of stroke / Инсульт, \% & 8.6 & 4.1 & 4.3 & 6.5 & 4.4 \\
\hline History of Ml / ИM, \% & 54.8 & 43.5 & 25.6 & 42.0 & 32.5 \\
\hline Angina pectoris / Стенокардия напряжения, \% & 47.4 & 56.7 & 56.2 & 99.6 & 55.9 \\
\hline $\mathrm{PCl} /$ ЧKB, \% & 1.9 & 4.9 & 4.2 & 11.1 & 4.8 \\
\hline $\mathrm{CHF} / \mathrm{XCH}, \%$ & 65.4 & No data / Нет данных & 61.3 & 68.5 & 59.8 \\
\hline Hypertension / $\mathrm{A} \Gamma$, \% & 97.6 & 76.0 & 85.9 & 85.6 & 81.6 \\
\hline Diabetes mellitus / Сахарный диабет, \% & 11.5 & 14.0 & 7.9 & 17.6 & 10.5 \\
\hline Smoking / Курение, \% & 26.0 & 45.8 & 24.1 & 25.7 & 30.1 \\
\hline Dislipidemia / Дислипидемия, \% & 52.3 & 70.7 & 46.4 & 58.7 & 52.3 \\
\hline Obesity / Ожирение \% & 31.3 & 22.6 & 27.5 & 34.5 & 24.8 \\
\hline SBP, mm Hg / САД, мм рт.ст. & $142.0 \pm 2.5$ & $142.3 \pm 2.0$ & $139.7 \pm 0.8$ & $143.0 \pm 0.9$ & $139.3 \pm 0.6$ \\
\hline DBP, mm Hg / ДАД, мм рт.ст. & $86 \pm 1.4$ & $87.2 \pm 0.8$ & $85.6 \pm 0.4$ & $88.0 \pm 0.5$ & $85.6 \pm 0.3$ \\
\hline HR per min / ЧСС, уд/мин & $75.5 \pm 2.6$ & $73.1 \pm 1.1$ & $74.8 \pm 0.5$ & $73.8 \pm 0.7$ & $74.3 \pm 0.4$ \\
\hline BMI, kg/m² / ИМТ, кг/м² & $27.2 \pm 0.2$ & $27.3 \pm 0.5$ & $27.4 \pm 0.2$ & $28.6 \pm 0.35$ & $27.2 \pm 0.2$ \\
\hline \multicolumn{6}{|c|}{$\begin{array}{l}\text { MI - myocardial infarction; PCI - percutaneous coronary interventions; CHF - chronic heart failure, SBP - systolic blood pressure; DBP - diastolic blood pressure; } \\
\text { HR - heart rate; BMI - body mass index }\end{array}$} \\
\hline \multicolumn{6}{|c|}{$\begin{array}{l}\text { ИМ - инфаркт миокарда; ЧКВ - чрескожное коронарное вмешательство; ХСН - хроническая сердечная недостаточность; АГ - артериальная гипертония; } \\
\text { САД - систолическое артериальное давление; ДАД - диастолическое артериальное давление; ЧСС - частота сердечных сокращений; ИМТ - индекс массы тела }\end{array}$} \\
\hline
\end{tabular}

litus was only registered in $10.5 \%$ of the patients ( 8 $17.6 \%$ ). Lipid metabolism disturbances were present in more than a half of the patients. One in four patients was obese; mean BMl exceeded $27 \mathrm{~kg} / \mathrm{m}^{2}$ in all the studies. It should be noted that heart rate exceeded 75 beats per min in all the IHD patients.

So, the IHD patients enrolled into these studies were almost similar in the main disease structure and incidence of comorbidity.

Comparing characteristics of the enrolled IHD patients with other Russian studies it was revealed that in the PRIMA study [17], which included similar patients (mean age 60.3 years; previous MI in 61.3\%) arterial hypertension was registered in $83 \%$ of patients, CHF - in $76 \%$ and diabetes - in 14.1\%. $28 \%$ of the patients were obese, $19 \%$ were smokers. $5.6 \%$ of the patients underwent angioplasty. Russian part of the CLARIFY registry [18] with more than 2 thousands of Russian patients with stable IHD, which was initiated in 2010, included rather similar patients: $4.3 \%$ of the patients had a history of stroke, $78.3 \%$ - of $\mathrm{Ml}$, $28.6 \%$ underwent percutaneous coronary intervention $(\mathrm{PCI}), 16.7 \%$ of the patients suffered from diabetes, $77.8 \%$ had dyslipidemia, 20.0\% were smokers, $77.5 \%$ of the IHD patients had CHF symptoms. As compared to the foreign research data main distinctions were revealed in CHF prevalence, which exceeded the similar index in foreign studies by бет (СД) в анамнезе зарегистрирован только у 10,5\%, варьируя от 8\% до 17,6\%. Более чем у половины определялось нарушение липидного обмена. Каждый четвертый пациент имел ожирение, средний индекс массы тела во всех исследованиях превышал 27 кг/M². Следует особо отметить, что частота пульса у всех больных ИБС превышала 73 уд/мин.

Таким образом, по структуре основного заболевания и частоте сопутствующей патологии больные ИБС в данных исследованиях практически однородны.

При сравнении характеристик больных ИБС, включенных в анализ, с другими российскими исследованиями было обнаружено, что в исследовании ПРИМА [17], которое включало аналогичных больных (средний возраст 60,3 года; ИМ в анамнезе у 61,3\%), артериальная гипертония регистрировалась у $83 \%$ больных, ХCH - у $76 \%$, а СД - у 14,1\%. Ожирение наблюдалось у 28\%, курили - 19\% больных. Ангиопластику перенесли 5,6\% больных. Весьма схожими были характеристики больных российской части регистра КЛАРИФАЙ [18], начавшегося в 2010 г. и включающего более 2 тысяч российских больных стабильной ИБС, из которых инсульт перенесли 4,3\%, ИМ - 78,3\%, чрескожные коронарные вмешательства проведены у 28,6\% больных, сахарный диабет имели 16,7\%, дислипидемию - 77,8\%, курили 20,0\%, а симптомы ХСН были выявлены у 77,5\% больных ИБС. По сравнению с зарубежными данными основные различия наблюдаются в частоте XCH, в несколько раз пре- 


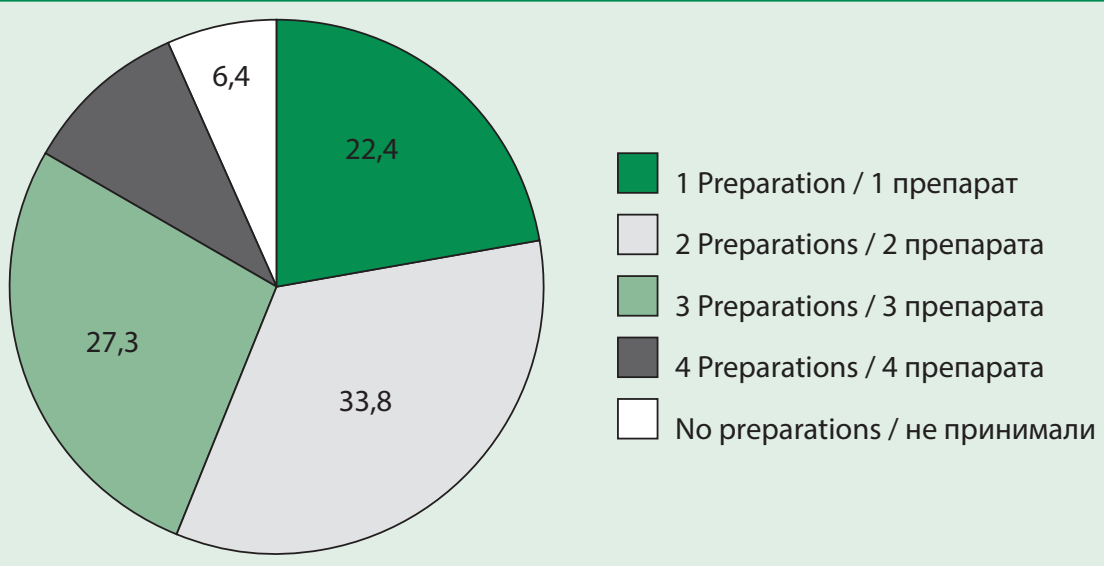

Figure 1. Distribution of the number of drugs received in IHD (\%)

Рисунок 1. Распределение числа принимаемых препаратов при ИБС (\%)

several times. Foreign patients smoke less frequently but more often have diabetes mellitus [18].

Analysis of prescribed medical treatment was carried out in gender-age groups in accordance with real distribution of medications in the studies. We evaluated dynamics in use of the following classes of drugs: ACE inhibitors and/or ARB, beta-blockers, antiplatelet agents, statins. $6.4 \%$ of the IHD patients were found to receive no medical treatment.

About one in five patients received 1 drug, a third of the patients used 2 and $37.4 \%-3$ and more medications (Fig.1).

Table 3 presents dynamics in the prescription of the examined classes of drugs depending on a year when a study was carried out. Men with IHD use antiplatelet agents more often than women. So, only $45.9 \%$ of women received these drugs in 2004 , $48.1 \%$ - in 2005 and $57.9 \%$ - in 2009 year, while antiplatelet agents intake in men increased from $58.5 \%$ in 2004 to $63.5 \%$ in 2009. Distinctions in the frequency of antiplatelet agents prescription were especially significant between men and women aged 3039 years in 2003 and 2009 years: women demonstrated almost two times less frequent intake of these drugs. Distinctions between the genders in other age groups were less significant. Interestingly, there was no notable dependence of antiplatelet agents prescription on age except for the mentioned above. We could not reveal any data in Russian literature about frequency of these drugs prescription depending on age, but our patients in general receive antiplatelet agents rather often. More than $80 \%$ of the PRIMA study patients also received antiplatelet agents [17]. It should be noted that according to the EUROASPIRE III (European Action on Secondary and Primary Prevention by Intervention to Reduce Events III) study, in which 22 European countries took part, 91\% of IHD patients received antiplatelet agents [19], what is cer- вышающей аналогичный показатель в международных практиках. Зарубежные больные реже курят, но СД у них регистрируется чаще [18].

Анализ назначений лекарственной терапии проводился в половозрастных группах с учетом фактического распределения препаратов в исследованиях. Рассматривалась динамика приема следующих классов препаратов: ИАПФ и/или БРА, БАБ, АТП, статинов. Оказалось, что 6,4\% больных ИБС вообще не принимали лекарственных препаратов.

Примерно каждый пятый пациент принимал 1 препарат, треть больных получали 2 препарата, 37,4\% - 3 и более препаратов (рис. 1).

В табл. 3 представлена динамика назначений изучаемых групп препаратов у больных ИБС в зависимости от года проведения исследования. Мужчины, страдающие ИБС, чаще принимают АТП, чем женщины. Так, в 2004 г. только 45,9\% женщин принимали этот класс препаратов, в 2005 г. - 48,1 \%, в 2009 г .- 57,9\%, тогда как прием АТП у мужчин увеличился с 58,5\% в 2004 г. до 63,5\% в 2009 г. Особенно велики различия в частоте назначений АТП между полами в возрастной группе 30-39 лет в 2003 и 2009 гг., где женщины демонстрируют почти в два раза меньшую частоту приема препаратов данного класса. В других возрастах различия между полами менее выражены. Интересно, что практически нет выраженной зависимости назначения АТП от возраста, за исключением указанного выше. Нам не удалось обнаружить в российской литературе данных по частоте назначений препаратов в зависимости от возраста, но в целом наши больные достаточно часто принимают АТП. В исследовании ПРИМА более 80\% аналогичных больных получали антиагреганты [17]. Следует отметить, что, по данным исследования EUROASPIRE III (European Action on Secondary and Primary Prevention by Intervention to Reduce Events III), в котором участвовали 22 страны Европы, АТП получали 91\% больных с клиническим диагнозом ИБС [19], что, конечно, выше, чем в российских исследованиях, проводившихся в это же время [16]. По данным междуна- 
Table 3. Frequency (\%) of the drugs intake in IHD based on gender, age and year of the study

Таблица 3. Частота (\%) приема лекарственных препаратов при ИБС в зависимости от пола, возраста и года исследования

\begin{tabular}{|c|c|c|c|c|c|c|c|c|}
\hline \multirow[t]{2}{*}{$\begin{array}{l}\text { Years/age } \\
\text { Годы/возраст }\end{array}$} & \multicolumn{2}{|c|}{$\begin{array}{c}\text { Antiplatelet agents, \% } \\
\text { Антитромбоцитарные препараты, \% }\end{array}$} & \multicolumn{2}{|c|}{$\begin{array}{l}\text { RAAS blockers, \% } \\
\text { Блокаторы PAAC, \% }\end{array}$} & \multicolumn{2}{|c|}{$\begin{array}{c}\text { Beta-blockers, \% } \\
\text { Бета-адреноблокаторы, \% }\end{array}$} & \multicolumn{2}{|c|}{$\begin{array}{l}\text { Statins, \% } \\
\text { Статины, \% }\end{array}$} \\
\hline & $\begin{array}{c}\text { Men } \\
\text { Мужчины }\end{array}$ & $\begin{array}{l}\text { Women } \\
\text { Женщины }\end{array}$ & $\begin{array}{c}\text { Men } \\
\text { Мужчины }\end{array}$ & $\begin{array}{l}\text { Women } \\
\text { Женщины }\end{array}$ & $\begin{array}{c}\text { Men } \\
\text { Мужчины }\end{array}$ & $\begin{array}{c}\text { Women } \\
\text { Женщины }\end{array}$ & $\begin{array}{c}\text { Men } \\
\text { Мужчины }\end{array}$ & $\begin{array}{l}\text { Women } \\
\text { Женщины }\end{array}$ \\
\hline \multicolumn{9}{|l|}{2004} \\
\hline 30 & 51.3 & 28.7 & 50.3 & 21.3 & 61.5 & 38.4 & 5.2 & 7.3 \\
\hline 40 & 60.3 & 40.1 & 63.9 & 60.7 & 65.2 & 58.5 & 12.6 & 11.5 \\
\hline 50 & 60.9 & 48.1 & 67.8 & 68.5 & 66.0 & 59.8 & 10.6 & 14.0 \\
\hline 60 & 61.4 & 51.8 & 71.5 & 72.0 & 61.1 & 55.9 & 6.8 & 10.9 \\
\hline 70 & 57.2 & 53.4 & 73.4 & 75.3 & 53.3 & 52.5 & 0.7 & 8.2 \\
\hline Total / Всего & 58.5 & 45.9 & 663 & 62.4 & 60.1 & 51.7 & 5.3 & 9.6 \\
\hline \multicolumn{9}{|l|}{2005} \\
\hline 30 & 53.2 & 52.6 & 70.9 & 39.4 & 68.4 & 60.6 & 19.8 & 4.7 \\
\hline 40 & 57.1 & 42.4 & 64.9 & 74.2 & 75.6 & 58.3 & 15.1 & 13.6 \\
\hline 50 & 58.1 & 41.9 & 72.6 & 71.5 & 72.8 & 57.4 & 15.5 & 12.7 \\
\hline 60 & 59.6 & 49.5 & 75.9 & 76.6 & 66.3 & 57.0 & 14.1 & 11.4 \\
\hline 70 & 55.3 & 49.6 & 78.7 & 80.8 & 56.6 & 55.7 & 78.7 & 66.7 \\
\hline Total / Всего & 60.8 & 48.1 & 75.8 & 69.8 & 64.9 & 56.9 & 13.5 & 10.9 \\
\hline \multicolumn{9}{|l|}{2009} \\
\hline 30 & 61.3 & 25.9 & 74.4 & 56.4 & 80.3 & 87.4 & 92.5 & 67.6 \\
\hline 40 & 62.5 & 52.3 & 82.0 & 77.6 & 79.3 & 73.0 & 95.7 & 69.7 \\
\hline 50 & 65.6 & 51.8 & 82.8 & 77.7 & 81.8 & 79.0 & 89.2 & 77.0 \\
\hline 60 & 63.7 & 61.5 & 82.4 & 78.6 & 73.6 & 81.1 & 86.1 & 73.6 \\
\hline 70 & 63.1 & 71.0 & 82.7 & 81.4 & 70.7 & 72.4 & 11.7 & 11.9 \\
\hline Total / Всего & 63.5 & 57.9 & 79.7 & 75.8 & 74.6 & 82.4 & 85.7 & 69.5 \\
\hline
\end{tabular}

tainly higher than in Russian studies that took place in the same period of time [16]. According to international IHD registry data more than $90 \%$ of Russian patients receive antiplatelet agents [18].

Intake of the renin-angiotensin-aldosterone system (RAAS) blockers (ACE inhibitors and ARB) had increased by about 13\% in 2009 as compared to 2004 year in patients of the both genders, at that frequency of these drugs use was almost similar in men and women (Table 3). The frequency of the RAAS blockers intake increases by 5-10\% with every age decade independent from gender except for 2004 year, when women of the youngest age group were prescribed these drugs significantly more seldom (21.3\%) than men of the same age (50.3\%) and elderly women (75.3\%). In 2009 already $79.7 \%$ of men and $75.8 \%$ of women received this class of drugs. The PRIMA study demonstrates similar indices: $76 \%$ of the enrolled patients received ACE inhibitors. EUROASPIRE III reports of $71 \%$ IHD patients receiving drugs of this class and CLARIFAY - about 75.9\%, at that $86 \%$ of the patients of the Russian part of the register were intaking the RAAS blockers [17-19]. родного регистра ИБС более $90 \%$ российских больных принимают АТП [18].

Прием препаратов, блокирующих ренин-ангиотензинальдостероновую (РААС) систему (ИАПФ и АРА), в 2009 г. по сравнению с 2004 г. увеличился у больных обоего пола примерно на 13\%, причем частота приема этих препаратов практически идентична у мужчин и женщин (табл. 3). С каждым десятилетием возраста частота приема блокаторов, РААС увеличивается на 5-10\% независимо от пола, за исключением 2004 г., в котором эти препараты назначались женщинам самой молодой возрастной группы существенно реже (21,3\% ) , чем мужчинам соответствующего возраста (50,3\%) и чем пожилым женщинам (75,3\% ). В 2009 г. эту группу препаратов принимали уже 79,7\% мужчин и 75,8\% женщин. Аналогичные показатели демонстрирует исследование ПРИМА, в котором 76\% больных принимали ИАПФ. EUROASPIRE III информирует о $71 \%$ больных ИБС, принимавших этот класс препаратов, а КЛАРИФАЙ 75,9\%, причем в российской части регистра 86\% больных принимали блокаторы РААС [17-19].

Анализ терапии БАБ показал, что в 2009 г. мужчины принимали этот класс препаратов на 14\% чаще (74,6\%), чем в 2004 г., а женщины - чаще на 30\% (82,4\%). Причем, у 
Analysis of beta-blockers use demonstrated their $14 \%$ more often intake in men in 2009 (74.6\%) than in 2004, and 30\% - in women (82.4\%). At that no changes have been revealed among both genders in frequency of these preparations intake depending on age. 30-39-year-old women in 2003 year were the exception; they were receiving beta-blockers less frequent. Other studies demonstrated similar results. In the PRIMA study $81.5 \%$ of men and $74.8 \%$ of women were prescribed beta-blockers [17].

According to our analysis data the most significant success has been achieved in lipid-lowering therapy - in particular, in statins prescription. Statins intake has increased from $5.3 \%$ to $85.7 \%$ in men and from $9.6 \%$ to $69.3 \%$ in women in the last 5 years. $2 / 3$ of the PRIMA study patients and $78 \%$ of the CLARIFY register patients received statins $[17,18]$.

Persons above 70 years old use statins less frequently, however we can not say about age distinctions in these drugs application. Besides, the highest frequency of statins intake was registered in 2009 year, 6-7 times exceeding the one in 2005.

\section{Conclusion}

It is worth mentioning in the conclusion, that frequency of prescription of drugs with established prognostic effect has increased in recent years, what was also demonstrated in other studies. At the same time, despite the cardiovascular mortality reduction, situation remains unfavorable. Proportion of the IHD mortality in the cardiovascular diseases mortality structure continues to be high perhaps, among other things, due to inadequate treatment. First, our patients far less frequently undergo interventions on coronary arteries than patients in other countries. Second, despite significant increase in frequency of medical preparations administration their doses and permanency of intake remain inadequate. So, according to Karpov Iu.A. and Deev A.D. data level of achievement of betablockers therapeutical doses was insufficient [20].

Third, high incidence rate of chronic heart failure in our patients may testify both for more severe disease course and for overdiagnosis, including one due to social reasons such as grounds for receiving disability status.

Finally, studies initiated by pharmacological companies usually take place in large centers with the most qualified professionals; this may lead to little changes in the results.

On the contrary, "IHD Prognosis" register demonstrated low frequency of prescription of drugs with established prognostic cardiovascular effect for secondary prevention in IHD patients before hospitalization and significant rise of it during treatment in больных обоего пола практически не отмечается изменений частоты приема этого класса препаратов с возрастом. Исключением являются женщины в возрасте 30-39 лет в 2003 г., когда отмечалась наименьшая частота приема БАБ. Аналогичные данные наблюдались и в других исследованиях. В исследовании ПРИМА БАБ принимали 81,5\% мужчин и 74,8\% женщин [17].

Как показал анализ, наибольший успех был достигнут при динамике назначений липидснижающей терапии, а именно, статинов. Прием статинов за пять последних лет увеличился с 5,3\% до 85,7\% у мужчин и с 9,6\% до 69,3\% у женщин. В исследовании ПРИМА принимали статины 2/3 больных, а в регистре КЛАРИФАЙ прием липидснижающей терапии отмечался у $78 \%$ больных $[17,18]$.

Нельзя сказать, что имеются возрастные отличия в приеме статинов, но чаще отмечается снижение приема этого класса препаратов после 70 лет. Кроме того, 2009 г. отличается наиболее высокой частотой приема статинов, в 6-7 раз выше, чем в 2005 г.

\section{Заключение}

В заключение стоит заметить, что частота назначения препаратов, обладающих прогностически доказанным действием, увеличилась за последние годы, это показано и в других исследованиях. Вместе с тем, ситуация остается неблагоприятной, несмотря на снижение смертности от ССЗ. Доля смертности от ИБС в структуре смертности от ССЗ остается высокой, что может быть связано, в том числе, с неадекватным лечением. Во-первых, число хирургических и интервенционных вмешательств на коронарных артериях у наших больных значительно ниже, чем в других странах. Во-вторых, несмотря на существенное увеличение частоты применения лекарственных препаратов, дозы и постоянство приема остаются недостаточными. Так, данные Карпова Ю.А. и Деева А.Д. показали недостаточный уровень достижения терапевтических доз БАБ [20].

В-третьих, высокая частота хронической сердечной недостаточности у наших больных может свидетельствовать как о более тяжелом течении заболевания, так и о гипердиагностике, в том числе и по социальным причинам (как обоснование для получения инвалидности).

И, наконец, исследования, инициируемые фармакологическими кампаниями, как правило, проводятся в крупных центрах, где работают наиболее квалифицированные специалисты, вследствие чего результаты могут быть несколько смещенными.

Напротив, результаты регистра «Прогноз ИБС» продемонстрировали низкую частоту назначения лекарственных препаратов с доказанным прогностическим влиянием на риск развития сердечно-сосудистых осложнений при вторичной профилактике у больных до госпитализации, и значительное увеличение ее в период пребывания в специализированном кардиологическом стационаре. Так, при выписке частота назначения ингибиторов АПФ выросла с $20 \%$ до 
specialized cardiac unit. Thus, at discharge from the hospital, frequency of ACE inhibitors prescription increased from $20 \%$ to $84.4 \%$, statins - from $10 \%$ to $85.56 \%$, beta-blockers - from $20 \%$ to $91 \%$, acetylsalicylic acid - from $74 \%$ to $96 \%$. However, statins were used in inadequate doses and target levels of low density lipoproteins cholesterol at discharge was only achieved in $6.3 \%$ of patients [21].

So, it is necessary to carry out representative research or organize registers with participation of different healthcare institutions: federal, republican, regional and district ones.

\section{Authors thank KRKA and SERVIER pharmaceuti-} cal companies for data provided and MEDTRONIC company for making it possible to carry out this analysis.

Disclosures. Shalnova S.A. had received a scientific grant from MEDTRONIC company; she is also a consultant of NOVARTIS, SERVIER, KRKA and ACTAVIS companies. Other authors claimed of no potential conflict of interest demanding disclosure in this article.

\section{References / Литература}

1. Fox CS, Evans JC, Larson MG, Kannel WB, Levy D. Temporal Trends in Coronary Heart Disease Mortality and Sudden Cardiac Death From 1950 to 1999. The Framingham Heart Study. Circulation 2004;110:522-7.

2. Ford ES, Capewell S. Proportion of the decline in cardiovascular mortality disease due to prevention versus treatment: public health versus clinical care. Annu Rev Public Health 2011;32:5-22.

3. Laatikainen T, Critchley J, Vartiainen E, et al. Explaining the decline in coronary heart disease mortality in Finland between 1982 and 1997. Am J Epidemiol 2005;162:764-73.

4. Health and demographic indices of Russian Federation in 2011. Statistical handbook. Moscow: Russian Ministry of Health; 2013. Russian (Медико-демографические показатели Российской Федерации в 2011 году. Статистический справочник. М.: Минздрав России; 2013).

5. Heidenreich PA, Trogdon JG, Khavjou OA, et al. Forecasting the Future of Cardiovascular Disease in the United States A Policy Statement From the American Heart Association. Circulation 2011; 123:93344.

6. Overall morbidity in the adult population in Russia in 2011. Statistical materials, parts III, IV. Moscow: Rosstat; 2012. Russian (Общая заболеваемость взрослого населения России в 2011 году. Статистические материалы, части III, IV. М.: Росстат; 2012)

7. Capewell S, Morrison CE, McMurray JJ. Contribution of modern cardiovascular treatment and risk factor changes to the decline in coronary heart disease mortality in Scotland between 1975 and 1994. Heart 1999;81:380-6

8. Unal B, Critchley JA, Capewell S. Modelling the decline in coronary heart disease deaths in England and Wales, 1981-2000: comparing contributions from primary prevention and secondary prevention. BMJ 2005;331:614

9. Aspelund T, Gudnason V, Magnusdottir BT, et al. Analysing the large decline in coronary heart disease mortality in the Icelandic population aged 25-74 between the years 1981 and 2006. PLoS One 2010;5(11):e13957.

10. Palmieri L, BennettK, Giampaoli S, Capewell S. Explaining the decrease in coronary heart disease mortality in Italy between 1980 and 2000. Am J Public Health 2010;100(4):684-92.

11. Ford ES, Capewell S. Proportion of the decline in cardiovascular mortality disease due to prevention versus treatment: public health versus clinical care. Annu Rev Public Health 2011;32:5-22.

12. 2013 ESC guidelines on the management of stable coronary artery disease: the Task Force on the management of stable coronary artery disease of the European Society of Cardiology. Eur Heart J 2013;34(38):2949-3003.

13. Chazov E.I., Oganov R.G., Poghosova N.V., et al. Depression in patients with arterial hypertension and coronary heart disease. The KOORDINATA clinical - epidemiological program: first results of multicenter study. Kardiologiiia 2005; (11): 4-10. Russian (Чазов Е.И., Оганов Р.Г., Погосова Н.В., и др. Клинико-эпидемиологическая программа изучения депрессии в кардиологической практике у больных артериальной гипертонией и ишемической болезнью сердца (КООРДИНАТА): первые результаты многоцентрового исследования. Кардиология 2005; (11): 4-10).

14. Shalnova SA, Deev AD. Characteristics of high-risk patients. The results of the epidemiological research and educational programs OSKAR. Cardiovascular Therapy and Prevention 2006; 6: 58-63. Russian (Шальнова С.А., Деев А.Д. Характеристика пациентов высокого риска. Результаты эпидемиологической части научно-образовательной программы ОСКАР. Кардиоваскулярная Терапия и Профилактика 2006; (6): 58-63).
84,4\%, статинов - с 10\% до 85,5\%, бета-адреноблокаторов - с 20\% до 91\%, ацетилсалициловой кислоты - с 74\% до 96\%. Тем не менее, статины применялись в неадекватных дозах, и целевой уровень холестерина липопротеинов низкой плотности при выписке был достигнут всего у 6,3\% пациентов [21].

Таким образом, целесообразно проведение представительных исследований или организации регистров с привлечением лечебно-профилактических учреждений разного уровня: федерального или республиканского, областного и районного.

Авторы выражают признательность фармацевтическим компаниям КРКА и СЕРВЬЕ за предоставленные данные и благодарят компанию МЕДТРОНИК за возможность выполнить данный анализ.

Конфликт интересов. Шальнова С.А. - получила научный грант компании МЕДТРОНИК, является консультантом для компаний Новартис, Сервье, КРКА, АКТАВИС. Остальные авторы заявили об отсутствии потенциального конфликта интересов, требующего раскрытия в данной статье.

15. Shalnova SA, Deev AD, Karpov YA. Hypertension and coronary heart disease in the actual practice of a cardiologist. Cardiovascular Therapy and Prevention 2006; 1: 73-80. Russian (Шальнова С.А., Деев А.Д, Карпов Ю.А. Артериальная гипертония и ишемическая болезнь сердца в реальной практике врача-кардиолога. Кардиоваскулярная Терапия и Профилактика 2006;(1): 73-80).

16. Bubnova MG, Aronov DM, Oganov RG, et al (on behalf of the researchers). Clinical characteristics and common approaches to the treatment of patients with stable angina in actual practice. Russian study PERSPEKTIVA (Part I). Cardiovascular Therapy and Prevention 2010; 9 (6): 47-56. Russian (Бубнова М.Г., Аронов Д.М., Оганов Р.Г., и др. (от имени исследователей). Клиническая характеристика и общие подходы клечению пациентов со стабильной стенокардией в реальной практике. Российское исследование ПЕРСПЕКТИВА (часть I). Кардиоваскулярная Терапия и Профилактика 2010; 9(6): 47-56).

17. Vasyuk YA, Shalnova SA, Shkolnik EL, Kulikov KG. The PRIMA study: trimetazidine modified release of the active ingredient in the treatment of patients with stable angina pectoris, myocardial infarction. Epidemiological and clinical stages. Kardiologiia 2008; 48 (12): 10-3. Russian (Вacюк Ю.A., Шальнова С.А., Школьник Е.Л., Куликов К.Г. Исследование ПРИМА: триметазидин с модифицированным высвобождением действующего вещества в лечении пациентов со стабильной стенокардией, перенесших инфаркт миокарда. Эпидемиологический и клинический этапы. Кардиология 2008; 48(12):10-3).

18. Shalnova SA, Oganov RG, Stag FG, Ford I. on behalf of the register CLARIFY Coronary Heart Disease Modern reality according to the World Register CLARIFY. Kardiologiia 2013; 53 (8): 28-33. Russian (Шальнова С.А., Оганов Р.Г., Стэг Ф.Г., Форд И. от имени участников регистра CLARIFY Ишемическая болезнь сердца. Современная реальность по данным всемирного регистра CLARIFY. Кардиология 2013; 53(8): 28-33)

19. Kotseva K, Wood D, De Backer G, De Basquerb D, Pyorala K, Keild U, EUROASPIRE Study Group. EUROASPIRE III: a survey on the lifestyle, risk factors and use of cardioprotective drug therapies in coronary patients from 22 European countries. Eur J Cardiovasc Prev Rehabil 2009; 16:121-37.

20. Karpov YA, Deev AD (on behalf of program participants). The ALTERNATIVA Program - Research antianginal effectiveness and tolerability of Procoralan (ivabradine) and evaluation of the quality of life patients with stable angina: results of epidemiological stages. Kardiologiia 2008; (5): 30-35. Russ$\operatorname{ian}($ Карпов Ю.А., Деев А.Д. (от имени участников программы). Программа АЛЬТЕРНАТИВА исследование АнтиангинаЛЬной эффекТивности и пЕРеносимости кораксаНА (ивабрадина) и оценка качесТва жИзни пациентоВ со сААбильной стенокардией: результаты эпидемиологического этапа. Кардиология 2008; 5: 30-5).

21. Tolpygina SN, Polyanskaya YN, Martsevich SYu. Treatment of patients with chronic coronary heart disease in real clinical practice according to the "IHD PROGNOSIS" registry data (Part 1). Rational Pharmacother Card 2013; 9 (2): 138-42. Russian (Толпыгина С.Н., Полянская Ю.Н., Марцевич С.Ю. Лечение пациентов с хронической ишемической болезнью сердца в реальной клинической практике по данным регистра «ПРОГНОЗ ИБС» (часть 1). Рациональная Фармакотерапия в Кардиологии 2013; 9(2): 138-42).

Received / Поступила: 18.11.2013 Accepted / Принята в печать: 29.11.2013 